\title{
Plant identification credibility in ethnobotany: a closer look at Polish ethnographic studies
}

\author{
Łukasz J Łuczaj
}

\begin{abstract}
Background: This paper is an attempt to estimate the percentage of erroneously identified taxa in ethnographic studies concerning the use of plants and to propose a code for recording credibility of identification in historical ethnobotany publications.

Methods: A sample of Polish-language ethnobotanical literature (45 published sources from 1874-2005) and four collections of voucher specimens (from 1894-1975) were analyzed. Errors were detected in the publications by comparing the data with existing knowledge on the distribution of plant names and species ranges. The voucher specimens were re-examined.

A one-letter code was invented for quick identification of the credibility of data published in lists of species compiled from historical or ethnographic sources, according to the source of identification: voucher specimen, Latin binominal, botanical expert, obvious widespread name, folk name, mode of use, range, physical description or photograph. To test the use of the code an up-to-date list of wild food plants used in Poland was made.

Results: A significant difference between the ratio of mistakes in the voucher specimen collections and the ratio of detectable mistakes in the studies without herbarium documentation was found. At least $2.3 \%$ of taxa in the publications were identified erroneously (mean rate was 6.2\% per publication), and in half of these mistakes even the genus was not correct. As many as $10.0 \%$ of voucher specimens (on average $9.2 \%$ per collection) were originally erroneously identified, but three quarters of the identification mistakes remained within-genus.

The species of the genera Thymus, Rumex and Rubus were most often confused within the genus.

Not all of the invented credibility codes were used in the list of wild food plants, but they may be useful for other researchers. The most often used codes were the ones signifying identification by: voucher specimen, botanical expert and by a common name used throughout the country.

Conclusions: The results of this study support the rigorous use of voucher specimens in ethnobotany, although they also reveal a relatively high percentage of misidentified taxa in the specimens studied.

The invented credibility coding system may become a useful tool for communication between historical ethnobotanists, particularly in creating larger databases.
\end{abstract}

\section{Background}

One of the main problems ethnobotanists face when publishing their results is the possibility of a mistake in the identification of the studied taxa. Therefore securing voucher specimens is now standard procedure in ethnobotany [1-3], required by major journals and discussed in ethnobotany method manuals [e.g. $[4,5]]$. On the other hand the results of studies not documented by voucher specimens are still sometimes published,

Correspondence: lukasz.luczaj@interia.pl

The Wild Garden; Pietrusza Wola 86; 38-471 Wojaszówka; Poland particularly in the field of historical ethnobotany, where not only is there a lack of voucher specimens, but often we have to hypothesize about the taxonomic position of certain species known only by their extinct folk/local names [6]. Ethnobotanists may include sources in their databases, which contain Latin binominals that come from reliable authors (preferably from professional botanists), but which are not confirmed by voucher specimens. This situation comes about because historical data are often too important to be discarded just on the basis of insufficient documentation [7]. 
It seems that no one has ever endeavored to estimate the possible percentage of mistakes in ethnobotanical publications. One of the very few authors who has dealt with the credibility of data in historical ethnobotany is Svanberg [8,9]. He presented a few examples of some so called "ghost data" - old and erroneous information, which has been repeated by subsequent authors. The importance of identification credibility in historical ethnobotany can be clearly shown by the study of Kufer et al. [10], who compared present use of plants by the Ch'orti' Maya from Guatemala with data gathered in the same population in the 1930 s by Charles Wisdom. It turned out that some mistakes occurred in the former study, where a taxon was misidentified as belonging to a different family.

The quality of ethnobotanical information is increasingly discussed in a variety of contexts [11-13], for instance ethnobotanical databases $[14,15]$. For example in a database of ethnobotanical data on the Campania region in Italy [14], levels of certainty of identification were introduced (sure, unsure, etc.). Generally, the likelihood of a mistake in identification probably increases with the age of the studied publication/information. This happens for a variety of reasons, e.g. changing folk names or uses in time.

In order to analyze the issue of mistakes in plant identification we should look at the whole process of plant identification. With ethnobotanical data a few scenarios are most likely:

1. The plant was shown to the ethnobotanist by an informant.

1.1 The informant showed the wrong plant.

1.2 The informant showed the right plant.

1.2.1 The plant was not taken from the field and the identification was performed "from memory".

1.2.2 The plant was picked and used in the identification process.

1.2.2.1 The plant was not preserved.

1.2.2.1.1 A voucher specimen was not made.

1.2.2.1.2 A voucher specimen was made later. from a plant, which according to the ethnobotanist's knowledge belongs to the same taxon.

1.2.2.2 The plant was preserved as a voucher specimen.

2 The plant was not shown to the ethnobotanist.

2.1 The plant was named by the informant using a local name.

2.1.1 A scientific name was not assigned.

2.1.2 The scientific name was found/hypothesized using other ethnobotanical literature containing the same or similar folk names as used in the studied population.

2.1.3 The local name is identical or similar to an official 'scientific' name of a species and the plant was (often erroneously) identified by assuming that the local name referred to the same taxon.

2.2 The plant was named by the informant using its scientific name (and a local name).

2.3 The plant was identified by the ethnobotanist from a verbal description.

Obviously the ideal situation is 1.2.2.2, particularly if voucher specimens were shown/brought by more than one informant. However, different scenarios happen for a variety of reasons, of which the major three are:

1 the ignorance of the researcher,

2 the fact that the information may be published/ recorded even if securing of a voucher specimen is not possible, because of the importance of studying the use of a taxon for the researcher,

3 the use of a plant is extinct and we have only historical records without voucher specimens.

In this study I would like to consider the problem of the credibility of ethnobotanical data in one country Poland. Poland, like a few other European countries, has a rich 19 and $20^{\text {th }}$ century ethnographic literature concerning the traditional use of plants - for a bibliography see Klepacki's review [16]. As the Polish flora is relatively poor in plant species (it has approximately three thousand species), the concept of voucher specimens was difficult to understand, not only for ethnographers studying the traditional use of plants, but also for botanists, who were relatively sure of their identifications.

The first person who tried to verify the credibility of older ethnobotanical studies in Poland was Köhler in 1996 [17], who checked the identification of plants in Udziela's herbarium from the turn of the $19^{\text {th }}$ and $20^{\text {th }}$ century. A few years earlier Radwańska-Paryska [18] reexamined the herbarium of an $18^{\text {th }}$ century monk, Brother Cyprian, containing Slovak and Polish plant names from the Pieniny and Tatra mountain ranges bordering the two countries. Later, the author of this paper ( ŁŁ) published an article on the taxonomic issues concerning the quality of the data and mistakes in the identification of taxa in ethnobotanical studies in Poland [19].

The aim of this article is to extend the investigations of the previous work [19], in particular:

1. To quantify a possible percentage of taxonomic errors in publications from this field.

2. To propose a standard of coding the credibility of identification of scientific names in ethnobotanical 
publications, and test its usefulness by making a list of edible plants used in Poland.

\section{Methods}

A sample of Polish-language ethnobotanical literature consisting of 45 published sources [20-64] (Table 1) and four voucher specimen collections were analyzed (Table 2 ). The analyzed publications consisted of a large proportion of Polish-language ethnographic publications with ethnobotanical content, which contained lists of regionally used plants including at least one Latin name. All such papers available to the author were taken into account. Most of the analyzed sources deal with either wild food plants (reviewed in the Journal of Ethnobiology and Ethnomedicine in 2007 [65]) or medicinal plants. Papers without Latin binominals or monographs on the use of single species were not included. Maurizio's [66] and Moszyński's [67,68] major works were not taken into account, as they are syntheses concerning the whole of northern Eurasia (the former author) or all Slavs (the latter). Lists of plant names and databases compiled mainly on the basis of other published sources were not included either [e.g. [69-71]]. The analyzed publications usually concern studies from the present area of Poland and in a few cases - western Belarus [44,45,47], western Ukraine [37] and Lithuania [56]. The publications from these countries were included in the analyses as they were written by Polish ethnographers working close to the present area of Poland, within its former, broader territory from before World War II.

The total number of identified plant taxa was recorded for each publication, as well as the number of taxa which were presumably identified erroneously. A reference to a species from one publication and each herbarium specimen were later referred to as a use-report, a term, which, although mainly applied to indicate a plant-use mentioned by a given informant [72], in this case can be used with a publication as a unit. This way of treating a literature citation as one use-report is used in ethnobotanical studies, which review earlier publications, where the number of informants and informant consensus is not given. For example this approach was used by Leonti et al. [73] to analyze the influence of the $16^{\text {th }}$ century herbal of Matthioli on present day ethnobotanical knowledge in Campania (Italy), and in reviews of edible plants of Spain [74].

The following methods of identifying errors were used:

- For wild taxa the distribution was checked in the atlas of the distribution of Polish vascular plants [75] - if the species did not occur in the geobotanical region (kraina geobotaniczna as mapped by Matuszkiewicz [76]) of the publication, an error was assumed.
- Some taxa were widely used under one name and their 'identity' is obvious but a different Latin name had been erroneously assigned to this folk taxon. For example in one publication szatwia - Salvia officinalis was named S. pratensis, although the description of the plant without doubt refers to the former.

The second part of the study dealt with the re-examination of voucher specimens (Table 2). The voucher specimen collections for ethnobotanical data are extremely rare in Poland and so far only four such herbariums have been found:

1. The documentation of Udziela's study [61] of medicinal and ritual plants of the Kraków area, stored in the Herbarium of the Institute of Botany of the Polish Academy of Sciences in Kraków (KRAM). The whole collection (119 specimens) was already previously checked by Köhler [17] but in 2010 I reexamined the collection. The specimens probably come from 1894-99 when Udziela collected his field data [17].

2. The documentation of Orzeszkowa's ethnobotanical study from the river Niemen region (now western Belarus) published in a few parts in the periodical Wista between 1888 and 1891 [e.g. $[44,45]]$ stored in the archive of the Poznańskie Towarzystwo Przyjaciół Nauk society in Poznań. The detailed description of this herbarium was published by Kielak [77]. Kielak's book contains colour photographs of around half of the voucher specimens in the archive (129 specimens out of 280). Plants were re-identified using photographs from this book.

3. The archives of the Polish Ethnographic Atlas study of wild edible plants from 1948-49 and medicinal plants from 1949-50 [78]. The herbarium (as a part of the field questionnaires) is stored in the office of the Polish Ethnographic Atlas in Cieszyn (University of Silesia) but formally belongs to the Polish Folklore Society in Wrocław. For this study 196 questionnaires (concerning edible plants) containing herbarium specimens, identified with Latin names, were used. The person who identified them is not recorded, the name of the Department of Plant Systematics and Geography of the University of Curie-Skłodowska in Lublin is printed as the identifying institution. The content of these questionnaires was published in 2008 with identifications already corrected by Łuczaj [79] - however in this study the original identifications were analyzed with reference to the kinds of errors that were made. The archive contains a few hundred more voucher specimens but they were not included in this study as 
Table 1 Literature sources [20-64] where the level of botanical mistakes was assessed using comparative methods (using the present knowledge of species ranges and the distribution of folk names)

\begin{tabular}{|c|c|c|c|c|c|}
\hline Author's name & Reference Number & Year & Main topic & No. of taxa with Latin names & Errors \\
\hline Bohdanowicz & {$[20]$} & 1996 & food & 10 & 2 \\
\hline Chętnik & [21] & 1936 & food & 14 & 0 \\
\hline Dekowski & [22] & 1968 & food & 35 & 0 \\
\hline Dekowski & [23] & 1973 & foraging & 38 & 0 \\
\hline Dydowiczowa & [24] & 1964 & foraging & 44 & 0 \\
\hline Eljasz-Radzikowski & {$[25]$} & 1897 & general ethnographic & 18 & 0 \\
\hline Gajkowa & [26] & 1947 & general ethnographic & 4 & 3 \\
\hline Gawełek & {$[27]$} & 1910 & ethnomedicine & 36 & 0 \\
\hline Gustawicz & [28] & 1904 & general ethnographic & 18 & 0 \\
\hline Henslowa & [29] & 1962 & selected edible taxa & 12 & 0 \\
\hline Janicka-Krzywda & {$[30]$} & 2004 & food & 5 & 1 \\
\hline Jostowa & [31] & 1954 & food & 1 & 0 \\
\hline Kantor & {$[32]$} & 1907 & general ethnogr. & 46 & 5 \\
\hline Kolberg & {$[33]$} & $1962(1874)$ & general ethnogr. & 54 & 1 \\
\hline Kolberg & [34] & $1962(1882)$ & general ethnogr. & 35 & 1 \\
\hline Kolberg & {$[35]$} & $1962(1891)$ & general ethnogr. & 75 & 0 \\
\hline Kolberg & {$[36]$} & 1973 & general ethnogr. & 6 & 0 \\
\hline Kolberg & {$[37]$} & $1963(1888)$ & general ethnogr. & 22 & 0 \\
\hline Kolberg & [38] & 1968 & general ethnogr. & 29 & 0 \\
\hline Libera, Paluch & [39] & 1993 & ethnomedicine & 98 & 0 \\
\hline Łęga & {$[40]$} & 1961 & general ethnogr. & 2 & 0 \\
\hline Malicki & [41] & 1971 & foraging & 20 & 0 \\
\hline Ochrymowicz & {$[42]$} & 1900 & beliefs about herbs & 52 & 1 \\
\hline Oczykowski & [43] & 1896 & ethnomedicine & 10 & 1 \\
\hline Orzeszkowa & [44] & 1888 & ethnomedicine and beliefs & 69 & 0 \\
\hline Orzeszkowa & {$[45]$} & 1891 & ethnomedicine and beliefs & 51 & 0 \\
\hline Paluch & {$[46]$} & 1984 & ethnomedicine & 176 & 0 \\
\hline Pietkiewicz & [47] & 1928 & material culture & 23 & 0 \\
\hline Plichta & [48] & 1891 & ethnomedicine & 8 & 0 \\
\hline Ruszel & [49] & 2004 & ethnographic dictionary & 85 & 8 \\
\hline Siarkowski & {$[50]$} & 1890 & ethnomedicine & 17 & 0 \\
\hline Siarkowski & [51] & 1891 & ethnomedicine & 5 & 1 \\
\hline Sulisz & {$[52]$} & 1906 & general ethnogr. & 11 & 3 \\
\hline Sulisz & [53] & 1906 & general & 8 & 4 \\
\hline Szot-Radziszewska & [54] & 2005 & ethnomedicine & 129 & 4 \\
\hline Szromba-Rysowa & {$[55]$} & 1966 & foraging & 63 & 2 \\
\hline Szukiewicz & {$[56]$} & 1903 & folk beliefs & 5 & 0 \\
\hline Szulczewski & {$[57]$} & 1996 & general ethnogr. & $>100$ & 0 \\
\hline Szychowska-Boebel & {$[58]$} & 1972 & ethnomedicine & 95 & 1 \\
\hline Szychowska-Boebel & [59] & 1978 & ethnomedicine & 49 & 1 \\
\hline Tylkowa & {$[60]$} & 1988 & ethnomedicine & 81 & 4 \\
\hline Wawrzeniecki & [61] & 1916 & ritual plants & 14 & 2 \\
\hline Weryho & {$[62]$} & 1888 & ethnomedicine & 31 & 1 \\
\hline Wysłouchowa & [63] & 1896 & general ethnogr. & 38 & 0 \\
\hline Udziela & [64] & 1931 & ethnomedicine and beliefs & 141 & 0 \\
\hline
\end{tabular}

they were only recently rediscovered and have not been analyzed in detail.

4. The herbarium of Szychowska-Boebel, stored in the archive of the Ethnographic Museum in Torun.
It is a documentation of her studies of ethnomedicinal plants in the village of Wiele in Eastern Pomerania in 1975 [59]. It contains 43 specimens, including 21 identified taxa. 
Table 2 Voucher specimen collections analyzed

\begin{tabular}{lcccc}
\hline Author's name & $\begin{array}{c}\text { Publication place of original } \\
\text { names }\end{array}$ & $\begin{array}{c}\text { Publication place of corrected } \\
\text { names }\end{array}$ & $\begin{array}{c}\text { No. of voucher specimens } \\
\text { analyzed }\end{array}$ & $\begin{array}{c}\text { No. of } \\
\text { errors }\end{array}$ \\
\hline Udziela & {$[61]$} & {$[17]$} & 119 & 8 \\
Orzeszkowa & {$[44,45]$} & partly in $[77]$ & 129 & 8 \\
Gajek & unpublished & {$[79]$} & 196 & 28 \\
Szychowska- & {$[59]$} & - & 21 & 2 \\
Boebel & & & \\
\hline
\end{tabular}

Both in publications and voucher specimen collections, only taxonomic errors were taken into account. Spelling mistakes were not included, nor were cases where the author was cautious and identified only the genus (for example Equisetum sp. instead of Equisetum hyemale). However the cases when only one species was reported in the literature as used in the area, though we have firm evidence that a larger number of closely related species was/is utilized were also treated as errors (inaccuracies), for example, a passage like: "blackberries (Rubus caesius) are used as food", as "Rubus caesius" should be replaced by "Rubus subgenus Rubus" or "Rubus spp."

The author set up a code of credibility for presentation of historical ethnobotanical data in tables:

$\mathrm{H}$ - confirmed by (a) voucher specimen(s),

A - confirmed by authority (expert botanist),

$\mathrm{O}$ - obvious common name universally used in a large area,

L - highly probable Latin name or a binominal scientific name used in the language of a given country corresponding to a Latin name, given by non-botanist,

$\mathrm{N}$ - identified using comparative analysis of folk names,

$\mathrm{M}$ - identified using data on the species' mode of use (in case of unusual species/uses),

D - identified using physical description of species,

$\mathrm{R}$ - identified with the help of the data of a species range or/and habitat,

$\mathrm{U}$ - highly uncertain (should be combined with another code),

$P$ - identified using pictures (photographs or drawings).

The usefulness of such a code was tested by compiling an up-to-date list of wild food plants used in Poland from the $19^{\text {th }}$ to $21^{\text {st }}$ century (within the present territory, excluding the German population pre-1939). The list was based on the review of edible plants of Poland [65] and amended by recent publications by Łuczaj [79-81] and Pirożnikow [82,83] bringing more data on the subject.

\section{Results}

Forty-six identification mistakes were detected both in the published material using comparative methods
(Tables 1 and 3) and in the voucher specimens (Tables 2,4 and 5). This constitutes $2.3 \%$ of the analyzed usereports for the former set of data and $10.0 \%$ of voucher specimens. The mean mistakes rates per publication differ significantly between the two sets of data (MannWhitney $\mathrm{U}$ test, $\mathrm{U}=35.5, \mathrm{P}$ (exact version $)=0.032, \mathrm{P}$ $($ Monte Carlo version $)=0.022)$, they were $6.2 \%$ and $9.2 \%$ respectively.

The comparative method revealed a relatively large number of mistakes in a few publications, both older $[26,32,52,53]$ and new ones $[49,54,60]$, however no or single mistakes were found in most sources.

There was no correlation between the year of publication and the percentage of errors in the species list (Pearson correlation coefficient, $r=-0.004, \mathrm{P}=0.98$, Kolberg's postmortem publications were assigned to his death date of 1890). Longer lists of plants had slightly lower error rates (the correlation between the number of Latin binominals in a list and the percentage of errors in it was $r=-0.28, \mathrm{P}=0.060$ ).

The mistakes concerned a variety of taxa but only a few taxa were mistaken more than twice: Thymus, ten times (e.g Thymus serpyllum confused with Thymus pulegioides or T. vulgaris), Rubus (six), Rumex (six), Cirsium, Trifolium (both four), Chenopodium/Atriplex, Malva and Mentha (three each). When the taxa from two families were confused this usually happened because of two similar folk/scientific names (e.g. Chenopodium - 'lebioda', Origanum vulgare - 'lebiodka'; Hippophae rhamnoides -' rokitnik', narrow leaved Salix spp. - 'rokita', etc.), which suggests that the author looked up Latin names in a scientific key without illustrations. This kind of error was the commonest type of mistake (eighteen out of thirty-six errors where a possible reason for the error was identified). The second commonest type (twelve cases) were simplifications and inaccuracies - such as reporting the use of only one species when more species from the same genus were used at least as frequently (Table 3 ).

In the list of edible plants of Poland (Table 6) 39\% of 192 use-reports are confirmed by voucher specimens (code $\mathrm{H}$ ), 30\% by scholars with reliable botanical expertise (code A), 13\% using folk names known widely throughout the country and $11 \%$ by scientific names 
Table 3 Errors detected in the studied publications, assessed using comparative methods

\begin{tabular}{|c|c|c|c|}
\hline Author & $\begin{array}{l}\text { Name in the publication } \\
\text { (with original spelling) }\end{array}$ & The correct name & Type of mistake/inaccuracy \\
\hline $\begin{array}{l}\text { Bohdanowicz } \\
{[20]}\end{array}$ & Origanum vulgare & Chenopodiumsp. & $\mathrm{L}$ \\
\hline $\begin{array}{l}\text { Bohdanowicz } \\
{[20]}\end{array}$ & Carduus & Cirsium sp. & L \\
\hline Gajkowa [26] & cuminum cyminum & Carum carvi L. & L \\
\hline Gajkowa [26] & panicum miliaceum & Echinochloa crus-galli (L.)P.Beauv. & L \\
\hline Gajkowa [26] & atriplex hortense & Chenopodium \& Atriplex spp. & L \\
\hline $\begin{array}{l}\text { Janicka- } \\
\text { Krzywda [30] }\end{array}$ & Carlina vulgaris & Carlina acaulis L. & $?$ \\
\hline Kantor [32] & Geranium & Dahlia sp. & $?$ \\
\hline Kantor [32] & Iris & Lilium sp.? & $?$ \\
\hline Kantor [32] & Salsola & $?$ & $?$ \\
\hline Kantor [32] & Selinum carvifolia & Carum carvi L. & 1 \\
\hline Kantor [32] & Sesleria coerulea & $\begin{array}{l}\text { Sesleria sadlerana Janka ssp. tatrae (Degen) } \\
\text { Deyl? }\end{array}$ & I \\
\hline Kolberg [33] & Hippophae rhamnoides & Salix sp. & $\mathrm{L}$ \\
\hline Kolberg [34] & Helleborus albus & $\begin{array}{l}\text { Veratrum sp.? Vincetoxicum hirundinaria } \\
\text { Medik.? }\end{array}$ & L \\
\hline $\begin{array}{l}\text { Ochrymowicz } \\
{[42]}\end{array}$ & Iris germanica & Iris sp. or Eupatorium cannabinum L. & $?$ \\
\hline $\begin{array}{l}\text { Oczykowski } \\
{[43]}\end{array}$ & Rumex hydrolapathum & some other Rumex spp. & । \\
\hline Ruszel [49] & Plantago major & Plantago spp. & S (the name refers to all the Plantago species) \\
\hline Ruszel [49] & Helleborus viridis & Veratrum lobelianum Bernh.? & $\mathrm{L}$ \\
\hline Ruszel [49] & Carum carvi & Glechoma hederacea L. s.l. & $?$ \\
\hline Ruszel [49] & Thymus serpyllum & $\begin{array}{l}\text { Thymus serpyllum L. em. Fr. \&Th. pulegioides } \\
\text { L. }\end{array}$ & S (both species are used) \\
\hline Ruszel [49] & Tilia cordata & Tilia cordata Mill. \&T. platyphyllos Scop. & S (both species are used equally frequently) \\
\hline Ruszel [49] & Rubus plicatus & Rubus subgenus Rubus spp. & $\begin{array}{l}S \text { (there are a few dozen species of Rubus in this area, } \\
\text { R. plicatus is not the most frequent [84] }\end{array}$ \\
\hline Ruszel [49] & Carduus & Cirsium \& Carduus spp. & $\mathrm{L}$ \\
\hline Ruszel [49] & Rumex hydrolapathum & Rumex spp. mainly $R$. obtusifolius $\mathrm{L}$. & I \\
\hline $\begin{array}{l}\text { Siarkowski } \\
\text { [51] }\end{array}$ & Thymus serpyllum & Thymus spp. & S \\
\hline Sulisz [52] & Origanum vulgare & Chenopodium sp. & L \\
\hline Sulisz [52] & Thymus vulgaris & $\begin{array}{l}\text { Thymus serpyllum L. em. Fr. or Th. pulegioides } \\
\text { L. }\end{array}$ & I \\
\hline Sulisz [52] & Matricaria Chamomilla & Tanacetum parthenium (L.) Sch.Bip. & 1 \\
\hline Sulisz [53] & Acorus calamus & Calamagrostis epigejos (L.)Roth & $?$ \\
\hline Sulisz [53] & Rhamnus cathartica & Staphylea pinnata $\mathrm{L}$. & $?$ \\
\hline Sulisz [53] & Galium cruciata & $\begin{array}{l}\text { Euonymus europaeus L./Rhamnus cathartica } \\
\text { L.? }\end{array}$ & $?(\mathrm{~L} ?)$ \\
\hline Sulisz [53] & Ledum palustre & $\begin{array}{l}\text { the term bagnięta was used erroneously as } \\
\text { it refers to any wooden branches }\end{array}$ & $\mathrm{L}$ \\
\hline $\begin{array}{l}\text { Szot- } \\
\text { Radziszewska } \\
\text { [54] }\end{array}$ & Cicuta virosa & Solanaceae, probably Hyoscyamus niger L. & L \\
\hline $\begin{array}{l}\text { Szot- } \\
\text { Radziszewska } \\
\text { [54] }\end{array}$ & Thymus serpyllum & Thymus spp. & S \\
\hline $\begin{array}{l}\text { Szot- } \\
\text { Radziszewska } \\
\text { [54] }\end{array}$ & Salvia pratensis & Salvia officinalis $\mathrm{L}$. & L \\
\hline $\begin{array}{l}\text { Szot- } \\
\text { Radziszewska }\end{array}$ & Papaver rhoeas & Papaver officinalis $L$. & L \\
\hline
\end{tabular}


Table 3 Errors detected in the studied publications, assessed using comparative methods (Continued)

\begin{tabular}{|c|c|c|c|}
\hline $\begin{array}{l}\text { Szromba- } \\
\text { Rysowa [55] }\end{array}$ & Rubus caesius & Rubus subgenus Rubus spp. & S (other Rubus spp. are used more frequently) \\
\hline $\begin{array}{l}\text { Szromba- } \\
\text { Rysowa [55] }\end{array}$ & Carduus sp. & Cirsium \& Carduus spp. & $\mathrm{L}$ \\
\hline $\begin{array}{l}\text { Szychowska- } \\
\text { Boebel [59] }\end{array}$ & Crataegus oxyacantha L. & Crataegus spp. & $\mathrm{S}$ (Crataegus monogyna is more frequent) \\
\hline $\begin{array}{l}\text { Szychowska- } \\
\text { Boebel [59] }\end{array}$ & Crataegus oxyacantha L. & Crataegus spp. & $\mathrm{S}$ (as above) \\
\hline Tylkowa [60] & Sonchus olearceus L. & Taraxacum sp. & $\mathrm{L}$ \\
\hline Tylkowa [60] & Rubus plicatus L. & Rubus spp. & $\begin{array}{l}\mathrm{S} \text { (there are a few dozen species of Rubus in this area, } \\
\text { R. plicatus is not the most frequent [84] }\end{array}$ \\
\hline Tylkowa [60] & Malva alcea $\mathrm{L}$. & Alcea rosea $\mathrm{L}$. & $\mathrm{L}$ \\
\hline Tylkowa [60] & Thymus serpyllum L. & Thymus pulegioides $\mathrm{L}$. & $\begin{array}{l}S-T \text {. serpyllum does not occur in the region, the } \\
\text { other species is commonly used }\end{array}$ \\
\hline $\begin{array}{l}\text { Wawrzeniecki } \\
\text { [61] }\end{array}$ & Thymus vulgaris & Thymus spp. & । \\
\hline $\begin{array}{l}\text { Wawrzeniecki } \\
\text { [61] }\end{array}$ & Urtica urens & Urtica dioica L. \& U. urens L. & $S$ \\
\hline Weryho [62] & Vinca major & Vinca minor L. & $?$ \\
\hline
\end{tabular}

with unknown reliability (L). Only ten out of 192 were identified using folk names $(\mathrm{N})$ and four by comparing species ranges ( $\mathrm{R}$; with help of other data, e.g. folk names). None of the species were identified by only using a physical description from literature (D), pictures (P) or mode of use $(\mathrm{M})$. In ten cases the code $\mathrm{U}$ (uncertain) was used.

\section{Discussion}

The lack of voucher specimens is obviously a problem in determining the real level of mistakes in older European ethnobotanical studies. A considerable number of errors was detected in the studied herbariums. The comparative analysis of species ranges and names did not reveal these mistakes. One may wonder to what extent other works can be trusted? Some ethnographers probably avoided making taxonomic mistakes by writing only about more common and widely known taxa and identifying taxa only to the genus level. Some authors mentioned in their publications that their study was documented by voucher specimens identified by a professional biologist (e.g. Orzeszkowa [77] and Wysłouchowa [64]) or that living/dried specimens were at least shown to professional botanists $[30,46]$ or that voucher specimens from the Polish Ethnographic Atlas were used [46]. Thus in the above mentioned cases the possibility of mistakes is much lower.

Some taxa are more likely to be confused than others. Unsurprisingly, errors often occur in genera with more than one species, in which the species are similar to each other and are poorly recognized in folk taxonomy, e.g. in the genera Mentha, Thymus, Tilia, Crataegus,
Rosa, Rumex and in the subgenus Rubus. The identification may be particularly difficult in apomictic taxa (like Rubus - [84]). Intergeneric mistakes occur either between two closely related genera not distinguished by folk taxonomy (Carduus and Cirsium) or less related (or unrelated) genera, if one of them has a folk name identical or similar to the scientific or folk name of another genus (in Poland, Origanum and Chenopodium, Sonchus and Taraxacum).

Nearly all of the quoted studies were performed by ethnographers, not botanists, so it is impossible to quantitatively compare the quality of their work with that of the few people with a biological background who have contributed to ethnobotany in Poland (e.g. Pirożnikow, Rostafiński, Maurizio, Moszyński, Szulczewski, though the latter two were known mainly as ethnographers). This comparison is particularly difficult given that most of these expert botanists supplied us with relatively large synthetic studies [66-69], and only Szulczewski and Pirożnikow contributed local monographs with ethnobotanical data $[57,82]$. Each of these studies [57,66-69,82] contains well over a hundred species. In five out of six of these works I have not encountered any identification mistakes. On the other hand in the work of Maurizio two mistakes can be suspected, which probably arose from the misidentification of folk taxa. Both concern famine plants used in Poland, quoted by the author. One of them is Cichorium, supposedly used as famine food in the Tatra mountains. Maurizio got this information from an ethnographic paper [25]. However the original source does not mention Cichorium but only a folk name - szczerbak. This folk name was used both for Cichorium intybus, Cirsium rivulare, as well as 
Table 4 Errors detected in the voucher specimen collections

\begin{tabular}{|c|c|c|}
\hline Collector & Name in the publication & The correct name \\
\hline Orzeszkowa & Anchusa arvensis & $?$ \\
\hline Orzeszkowa & Thymus serpyllum & Thymus pulegioides $\mathrm{L}$. \\
\hline Orzeszkowa & Anchusa arvensis & Anchusa officinalis $\mathrm{L}$. \\
\hline Orzeszkowa & Asarum europaeum & Hepatica nobilis L. \\
\hline Orzeszkowa & Sium latifolium & Cicuta virosa $\mathrm{L}$. \\
\hline Orzeszkowa & Ranunculus sceleratus & Ranunculus flammula $\mathrm{L}$. \\
\hline Orzeszkowa & Ranunculus flammula & Ranunculus sceleratus L. \\
\hline Orzeszkowa & Lamium maculatum & Lamiaceae but not Lamium \\
\hline Udziela & Arabis arenosa & Epilobium adenocaulon Hasskn. \\
\hline Udziela & Daucus carota & Pimpinella saxifraga $\mathrm{L}$. \\
\hline Udziela & Inula germanica & Inula britannica L. \\
\hline Udziela & Lappa maior (=Arctium lappa) & Arctium tomentosum Mill. \\
\hline Udziela & Marrubium vulgare & Nepeta cataria L. \\
\hline Udziela & Mentha piperita & Mentha cfr verticillata $\mathrm{L}$. \\
\hline Udziela & Thymus serpyllum & Thymus pulegioides $\mathrm{L}$. \\
\hline Udziela & Tilia grandiflora & Tilia cordata Mill. \\
\hline PAE & Betula alba & Betula pubescens Ehrh. \\
\hline PAE & Carlina vulgaris & Cirsium arvense (L.) Scop. \\
\hline PAE & Echium vulgare & Symphytum officinale L. \\
\hline PAE & Hypericum perforatum & Vaccinium uliginosum L. \\
\hline PAE & Malva neglecta (x3) & Malva sylvestris $L$. \\
\hline PAE & Mentha cfr. aquatica & Mentha longifolia (L.)Huds. \\
\hline PAE & Mentha piperita & Mentha longifolia (L.)Huds. \\
\hline PAE & Polygonum bistorta & Rumex acetosa L. \\
\hline PAE & Polygonum convolvulus & Convolvulus arvensis $\mathrm{L}$. \\
\hline PAE & Polygonum mite (x2) & Polygonum lapathifolium L. s.l. (including P. tomentosum Schrank) \\
\hline PAE & Ribes rubrum (x2) & Ribes spicatum Robson \\
\hline PAE & Rosa canina (x3) & Rosa sp. \\
\hline PAE & Rubus hirtus & Rubus sp. \\
\hline PAE & Rubus hirtus & Rubus caesius L. \\
\hline PAE & Rubus saxatilis & Rubus caesius L. \\
\hline PAE & Rumex acetosella & R. thyrsiforus Fing. \\
\hline PAE & Rumex acetosella L (x 2) & Rumex acetosa L. \\
\hline PAE & Thymus serpyllum (x2) & Thymus pulegioides $\mathrm{L}$. \\
\hline PAE & Trifolium medium & Trifolium repens $\mathrm{L}$. and T. pratense $\mathrm{L}$. \\
\hline PAE & Trifolium medium & Trifolium pratense L. \\
\hline Szychowska-Boebel & Trifolium arvense L. & Trifolium pratense $\mathrm{L}$. \\
\hline Szychowska-Boebel & Trifolium arvense $\mathrm{L}$. & Trifolium repens $\mathrm{L}$. \\
\hline
\end{tabular}

PAE - Polish Ethnographic Atlas (specimens collected by numerous researchers).

other Cirsium species [85]. Cirsium rivulare was a very important famine plant in the Tatras [85], whereas Cichorium intybus was never mentioned as famine food by any other source listed in this article. Another possible mistake concerns the use of Mellitis melisophyllum. Maurizio mentioned that this plant (he also cited the folk name miodnik) was used during famine in Poland. However this is a relatively rare plant. On the other hand there are a few species of plants, which were used as famine food under similar names (miodunka, medunka, miodownik), i.e.
Lamium spp., Symphytum officinale and Pulonaria obscura [65,79-81].

Even if these two mistakes were confirmed, the total ratio of mistakes in the works of the five professional botanists would remain well below half a percent. However, due to the different character of these studies, I restrained from deeper statistical comparisons.

It is worth pointing out that the quality of the ethnographers' work is highly variable. More than half of the publications contained no detectable mistakes, in 
Table 5 Comparison of error rates in the studied sources

\begin{tabular}{lcc}
\hline Type of study & Literature & $\begin{array}{c}\text { Voucher } \\
\text { specimens }\end{array}$ \\
\hline Number of publications/herbariums & 45 & 4 \\
\hline No. of use-reports/specimens & 1983 & 459 \\
\hline No. of errors detected & 46 & 46 \\
\hline Average rate of mistakes per publication/source & 6.2 & 9.2 \\
\hline Percentage of errors detected & 2.3 & 10.0 \\
\hline Types of errors: & Number of taxa (Percentage \\
& given in parentheses) \\
\hline wrong genus & $22(48 \%)$ & $11(24 \%)$ \\
\hline wrong species within the same genus & $7(15 \%)$ & $29(63 \%)$ \\
\hline more species from the same genus are actually used in the area & $16(35 \%)$ & - \\
\hline $\begin{array}{l}\text { the identification is too detailed (the voucher specimen is in bad condition - it should have been identified only to } \\
\text { the genus level) }\end{array}$ & - & 5 (11\%) \\
\hline
\end{tabular}

Table 6 The list of wild food plants used in Poland since the 19th century

\begin{tabular}{|c|c|c|c|c|c|}
\hline Species & Family & $\begin{array}{l}\text { Method of } \\
\text { Identification }\end{array}$ & Source & Parts Used & Mode of Use \\
\hline \multirow[t]{5}{*}{ Acer platanoides $\mathrm{L}$. } & Aceraceae & $\mathrm{H}$ & $1,2,5$ & sap & raw and fermented \\
\hline & & A & 1 & cambium & raw \\
\hline & & A & 1 & fruits & raw \\
\hline & & A & 1 & opening leaf buds & fermented \\
\hline & & A & 1,5 & leaves & under baking bread \\
\hline \multirow[t]{2}{*}{ Acer pseudoplatanus L. } & & A & 1,2 & sap & raw \\
\hline & & A & 1 & leaf buds & raw, ff \\
\hline Aegopodium podagraria $\mathrm{L}$. & Apiaceae & A & $3,5,6$ & young leaves & soup \\
\hline \multirow[t]{2}{*}{ Carum carvi $\mathrm{L}$. } & & $\mathrm{H}$ & $1,2,5$ & seeds & spice \\
\hline & & A & 1 & young plants & soup \\
\hline Daucus carota $\mathrm{L}$. & & A & 5,6 & roots, leaves, fruits & soup, spice \\
\hline Heracleum sphondylium L. & & $\mathrm{H}$ & $\begin{array}{l}1,2,3 \\
5,6\end{array}$ & leaves and flowering stalks & soup \\
\hline Pastinaca sativa $\mathrm{L}$. & & $\mathrm{O}$ & $1,2,6$ & roots & cooked foods \\
\hline \multirow[t]{2}{*}{ Acorus calamus $\mathrm{L}$. } & Araceae & $\mathrm{H}$ & $1,2,5$ & inner parts of stems & raw \\
\hline & & $\mathrm{H}$ & 1,5 & leaves & under baking bread \\
\hline Achillea millefolium L. & Asteraceae & A & $4,5,6$ & leaves & raw and as spice \\
\hline \multirow[t]{2}{*}{ Arctium sp. } & & A & 3 & leaf stalks & lacto-fermented \\
\hline & & A & 6 & roots & boiled \\
\hline Artemisia absinthium $\mathrm{L}$. & & $\mathrm{O}$ & 6 & leaves & spice for meat \\
\hline \multirow[t]{2}{*}{ Bellis perennis $\mathrm{L}$. } & & N & 2 & unspecified & unspecified \\
\hline & & A & 5,6 & flowers & raw \\
\hline Carlina acaulis L. & & $\mathrm{H}$ & $1,2,3$ & receptacles, roots & unknown \\
\hline Carlina vulgaris $\mathrm{L}$. & & U & 1 & unspecified parts & unkown \\
\hline Centaurea cyanus L. & & $\mathrm{H}$ & 1 & petals & fermented drink \\
\hline Chamomilla recutita (L.)Rauschert & & L & 2 & shoots & infusion \\
\hline \multirow[t]{2}{*}{ Cichorium intybus L. } & & U & 1,6 & leaves & boiled (ff), raw \\
\hline & & $L$ & $1,5,6$ & roots & coffee surrogate \\
\hline Cirsium oleraceum Scop. & & A & $1,3,4$ & leaves, roots & boiled, ff \\
\hline Cirsium rivulare All. & & $\mathrm{H}$ & $\begin{array}{l}1,2,3 \\
4\end{array}$ & leaves & boiled, ff \\
\hline Cirsium arvense (L.) Scop. & & $\mathrm{H}$ & $2,3,4$ & leaves, stalks & boiled, ff \\
\hline Sonchus arvensis $L$. & & LU & 1,3 & green parts & raw \\
\hline Taraxacum sp. pl. & & $A$ & 1,5 & inflorescences & syrup, wine \\
\hline
\end{tabular}


Table 6 The list of wild food plants used in Poland since the 19th century (Continued)

\begin{tabular}{|c|c|c|c|c|c|}
\hline & & $\mathrm{H}$ & $1,2,5$ & leaves & raw, boiled \\
\hline Tragopogon pratensis L. s.l. & & $\mathrm{H}$ & 2 & stalks & raw \\
\hline Tussilago farfara L. & & A & 1 & leaves & boiled, ff \\
\hline Berberis vulgaris $\mathrm{L}$. & Berberidaceae & $\mathrm{H}$ & $1,2,3$ & fruits & raw, preserves \\
\hline Alnus sp. & Betulaceae & $\mathrm{O}$ & 2 & & \\
\hline \multirow{3}{*}{$\begin{array}{l}\text { Betula pendula Roth \& Betula pubescens } \\
\text { Ehrh. }\end{array}$} & & $\mathrm{H}$ & $1,2,5$ & sap & raw or fermented \\
\hline & & $\mathrm{H}$ & 1 & leaf buds & fermented \\
\hline & & $\mathrm{H}$ & 1,2 & cambium & flour, ff \\
\hline Anchusa arvensis (L.) M.Bieb. & Boraginaceae & A & 3 & shoots & boiled, ff \\
\hline Echium vulgare L. & & A & 6 & flowers & nectar sucked \\
\hline Pulmonaria obscura L. & & $A R$ & 1 & leaves & boiled, ff \\
\hline \multirow[t]{3}{*}{ Symphytum officinale L. } & & $\mathrm{H}$ & $1,2,3$ & leaves & boiled, ff \\
\hline & & $\mathrm{H}$ & 2,6 & flowers & nectar sucked \\
\hline & & A & 6 & roots & boiled (ff?) \\
\hline \multirow{2}{*}{$\begin{array}{l}\text { Armoracia rusticana P.Gaertn., B.Mey, } \\
\text { \&Scherb. }\end{array}$} & Brassicaceae & $\mathrm{H}$ & $1,2,5$ & roots & spice \\
\hline & & A & 1 & leaves & $\begin{array}{l}\text { under baking bread or as } \\
\text { spice }\end{array}$ \\
\hline \multirow[t]{2}{*}{ Capsella bursa-pastoris (L.)Medik. } & & A & 1,2 & fruits & raw \\
\hline & & A & 5,6 & whole plant? & boiled \\
\hline Cardamine amara $\mathrm{L}$. & & $\mathrm{RU}$ & 3 & leaves & raw \\
\hline Cardamine pratensis L. & & A & 3 & leaves & $\mathrm{ff}$ \\
\hline Raphanus raphanistrum L. & & $\mathrm{H}$ & $\begin{array}{l}1,2,3 \\
4\end{array}$ & leaves & boiled, ff \\
\hline Sinapis arvensis L. & & $\mathrm{H}$ & $\begin{array}{l}1,2,3 \\
4\end{array}$ & leaves & boiled, ff \\
\hline Campanula persicifolia L. & Campanulaceae & $L$ & 1,6 & flowers & raw \\
\hline Phyteuma spicatum L. & & $L$ & 1 & roots & unspecified \\
\hline \multirow[t]{2}{*}{ Humulus lupulus L. } & Cannabaceae & $\mathrm{O}$ & $1,2,5$ & inflorescences and fruits & beer, mead, bread \\
\hline & & $\mathrm{O}$ & 1 & probably shoots & $\mathrm{ff}$ \\
\hline \multirow[t]{2}{*}{ Sambucus nigra L. } & Caprifoliaceae & $\mathrm{H}$ & $\begin{array}{l}1,2,3 \\
5,6\end{array}$ & fruits & $\begin{array}{l}\text { boiled: wine, jam, soup, } \\
\text { rarely raw }\end{array}$ \\
\hline & & $\mathrm{O}$ & 3,5 & flowers & fried in batter or preserves \\
\hline Viburnum opulus L. & & A & $1,2,5$ & fruits & boiled: wine, juice, jam \\
\hline Silene vulgaris (Moench) Garcke & Caryophyllaceae & A & 3 & shoots & boiled, ff \\
\hline Stellaria media (L.) Vill. & & N & 3 & shoots & boiled, ff \\
\hline Euonymus verrucosus Scop. & Celastraceae & A & 5 & fruits & added to wine? \\
\hline Atriplex patula L. & Chenopodiaceae & L? & 1 & leaves & boiled, fried \\
\hline Chenopodium album L. & & $\mathrm{H}$ & $\begin{array}{l}1,2,3 \\
5\end{array}$ & leaves & boiled, fried \\
\hline Chenopodium bonus-henricus L. & & A & 1,3 & leaves & boiled, fried \\
\hline Chenopodium hybridum L. & & A & 3 & leaves & boiled, fried \\
\hline Chenopodium polyspermum L. & & A & 3 & leaves & boiled, fried \\
\hline Chenopodium polyspermum L. & & A & 3 & leaves & boiled, fried \\
\hline Convolvulus arvensis L. & Convolvulaceae & $\mathrm{H}$ & $1,2,3$ & shoots & boiled, ff \\
\hline Carpinus betulus L. & Corylaceae & $\mathrm{H}$ & 1 & sap & raw \\
\hline \multirow[t]{2}{*}{ Corylus avellana L. } & & $\mathrm{H}$ & 1,3 & inflorescences, leaves & ff, mainly for flour \\
\hline & & $\mathrm{H}$ & $\begin{array}{l}1,2,3 \\
5\end{array}$ & fruits & raw and in cakes \\
\hline Juniperus communis L. & Cupressaceae & $\mathrm{O}$ & $1,2,5$ & pseudofruits & spice, beer, snack \\
\hline Scirpus sylvaticus L. & Cyperaceae & A & 1,6 & $\begin{array}{l}\text { inner parts of young } \\
\text { shoots }\end{array}$ & raw \\
\hline Pteridium aquilinum L. & Dennstaedtiaceae & LU & 1 & rhizomes & unspecified, ff \\
\hline
\end{tabular}


Table 6 The list of wild food plants used in Poland since the 19th century (Continued)

\begin{tabular}{|c|c|c|c|c|c|}
\hline Empetrum nigrum L. & Empetraceae & A & 1 & fruits & unspecified \\
\hline \multirow[t]{2}{*}{ Equisetum arvense L. } & \multirow[t]{2}{*}{ Equisetaceae } & $\mathrm{H}$ & $1,2,6$ & strobils & raw, cooked \\
\hline & & A & 2,6 & bulbils & raw \\
\hline Calluna vulgaris (L.) Hull ON & \multirow[t]{5}{*}{ Ericaceae } & $L$ & 1 & seeds & bread, ff \\
\hline Vaccinium myrtillus $\mathrm{L}$. & & $\mathrm{H}$ & $1,2,3$ & fruit & raw, boiled \\
\hline Vaccinium oxycoccos L. & & $\mathrm{H}$ & $\begin{array}{l}1,2,3 \\
5\end{array}$ & fruit & raw or in preserves \\
\hline Vaccinium vitis-idaea $\mathrm{L}$. & & $\mathrm{H}$ & $\begin{array}{l}1,2,3 \\
5\end{array}$ & fruit & raw or in preserves \\
\hline Vaccinium uliginosum L. & & $\mathrm{H}$ & $\begin{array}{l}1,2,3 \\
5\end{array}$ & & \\
\hline Euphorbia peplus L. & Euphorbiaceae & $L$ & 1 & whole plant & boiled, ff \\
\hline Astragalus glycyphyllos L. & \multirow[t]{5}{*}{ Fabaceae } & A & 5,6 & stalks & raw \\
\hline Medicago lupulina L. & & A & 6 & $\begin{array}{l}\text { thickened parts of the } \\
\text { roots }\end{array}$ & raw \\
\hline Robinia pseudoacacia L. & & $\mathrm{H}$ & 2 & flowers & raw, jams \\
\hline $\begin{array}{l}\text { Trifolium pratense } L \text {., } T \text {. repens } L \text {., } T \text {. } \\
\text { montanum } L \text {. }\end{array}$ & & $\mathrm{H}$ & 1,2 & inflorescences & $\begin{array}{l}\text { nectar sucked or dried for } \\
\text { baking bread }\end{array}$ \\
\hline Vicia sp. pl. & & $L$ & 1,2 & seeds & flour for bread, ff \\
\hline Fagus sylvatica $\mathrm{L}$. & \multirow[t]{2}{*}{ Fagaceae } & $\mathrm{H}$ & 1,3 & fruits & raw or baked, oil \\
\hline $\begin{array}{l}\text { Quercus robur L. \& Q. petraea Mattuschka } \\
\text { (Liebl.) }\end{array}$ & & $\mathrm{H}$ & 1 & fruits & flour (ff), coffee surrogate \\
\hline Ribes alpinum L. & \multirow[t]{6}{*}{ Grossulariaceae } & A & 5 & fruits & raw (rarely) \\
\hline Ribes alpinum L. or R. petraeum Wulfen & & NR & 1 & fruits & raw \\
\hline \multirow[t]{2}{*}{ Ribes nigrum L. } & & $\mathrm{H}$ & $1,2,6$ & fruits & raw, jams \\
\hline & & $\mathrm{H}$ & 1,6 & leaves & spice \\
\hline Ribes spicatum Robson & & $\mathrm{H}$ & 2,6 & fruits & raw, jams \\
\hline Ribes uva-crispa L. & & O & 2,3 & fruits & raw \\
\hline Stratiotes aloides $\mathrm{L}$. & Hydrocharitaceae & $\mathrm{H}$ & 2 & leaves, roots & boiled, ff \\
\hline Dracocephalum ruyschiana L. & \multirow[t]{15}{*}{ Lamiaceae } & A & 5 & flowers & nectar sucked \\
\hline Galeopsis sp. & & A & 1 & leaves & boiled, ff \\
\hline Glechoma hederacea L. s.l. & & $\mathrm{H}$ & $1,2,3$ & leaves & spice \\
\hline Lamium sp pl. (mainly L. album L.) & & A & 3 & shoots & boiled \\
\hline Lamium purpureum L. & & A & 5 & shoots & boiled \\
\hline \multirow[t]{2}{*}{ Melittis melisophyllum L. } & & LU & 1 & leaves & unspecified, ff; liquors \\
\hline & & A & 6 & flowers & nectar sucked \\
\hline Mentha arvensis L. & & $\mathrm{H}$ & 1,6 & leaves & spice, infusions, raw \\
\hline Mentha longifolia (L.)Hudson & & $\mathrm{H}$ & 1 & leaves & spice \\
\hline Origanum vulgare L. & & A & 1 & flowering tops & beer condiment \\
\hline Prunella vulgaris $\mathrm{L}$. & & N & 4 & shoots & boiled, ff \\
\hline Stachys palustris L. & & $\mathrm{H}$ & 2,3 & rhizomes & raw, boiled \\
\hline Thymus pulegioides $\mathrm{L}$. & & $\mathrm{H}$ & 1 & flowering tops & spice, teas \\
\hline Thymus serpyllum L. & & $\mathrm{H}$ & 1,5 & flowering tops & spice, teas \\
\hline Lemna minor L. & & $L$ & 1 & leaves & fried, ff \\
\hline \multirow[t]{2}{*}{ Allium ursinum $\mathrm{L}$. } & \multirow[t]{4}{*}{ Liliaceae } & LU & 1 & roots & spice \\
\hline & & $\mathrm{O}$ & $1,5,6$ & leaves & raw \\
\hline Allium sp. & & $\mathrm{N}$ & 2 & $?$ & $?$ \\
\hline Maianthemum bifolium (L.) F. W. Schmidt & & $\mathrm{H}$ & 1,3 & fruits & raw, wine \\
\hline Viscum album $\mathrm{L}$. & Loranthaceae & $\mathrm{H}$ & 2 & fruits & raw \\
\hline \multirow[t]{2}{*}{ Malva neglecta Wallr. } & \multirow[t]{4}{*}{ Malvaceae } & $\mathrm{H}$ & 1,2 & leaves & boiled \\
\hline & & $\mathrm{H}$ & $1,2,5$ & immature fruits & raw \\
\hline \multirow[t]{2}{*}{ Malva sylvestris $\mathrm{L}$. } & & $\mathrm{H}$ & 1,2 & leaves & boiled \\
\hline & & $\mathrm{H}$ & 1,2 & immature fruits & raw \\
\hline Fraxinus excelsior $\mathrm{L}$. & Oleaceae & O & 5,6 & fruits & boiled, ff \\
\hline
\end{tabular}


Table 6 The list of wild food plants used in Poland since the 19th century (Continued)

\begin{tabular}{|c|c|c|c|c|c|}
\hline Oenothera sp. & Onagraceae & A & 6 & roots & boiled \\
\hline Oxalis acetosella L. & Oxalidaceae & $\mathrm{H}$ & $\begin{array}{l}1,2,3 \\
5,6\end{array}$ & leaves & raw, cooked \\
\hline Oxalis stricta L. s.l. & & $\mathrm{H}$ & 1,2 & leaves & raw, cooked \\
\hline Papaver rhoeas $\mathrm{L}$. & Papaveraceae & $\mathrm{N}$ & 2,5 & seeds & unspecified \\
\hline Abies alba Mill. & Pinaceae & $\mathrm{O}$ & 1 & young shoots & syrup \\
\hline \multirow[t]{4}{*}{ Picea abies (L.) H. Karst. } & & $\mathrm{O}$ & 1 & young shoots & raw, syrup \\
\hline & & $\mathrm{O}$ & 1 & male inflorescences & raw \\
\hline & & $\mathrm{O}$ & 1 & young cones & raw \\
\hline & & O & 2 & cambium & $\mathrm{ff}$ \\
\hline \multirow[t]{2}{*}{ Pinus cembra L. } & & $\mathrm{O}$ & 1 & male inflorescences & raw \\
\hline & & $\mathrm{O}$ & 1 & seeds & raw \\
\hline Pinus sylvestris $\mathrm{L}$. & & $\mathrm{O}$ & 5 & $\begin{array}{l}\text { young vegetative and } \\
\text { generative shoots }\end{array}$ & raw, syrup \\
\hline Plantago lanceolata $\mathrm{L}$. & Plantaginaceae & $L$ & $1,2,6$ & leaves & boiled, raw \\
\hline Bromus secalinus L. & Poaceae & A & $1,2,3$ & seeds & ground for flour, ff \\
\hline Dactylis glomerata L. & & A & 1 & stem base & raw \\
\hline Elymus repens (L.) Gould & & $\mathrm{H}$ & 1 & rhizomes & ground for flour \\
\hline Festuca pratensis L. & & LU & 1 & seeds & unspecified \\
\hline Glyceria fluitans (L.) R. Br. & & A & 1 & seeds & seeds, boiled or for flour \\
\hline Glyceria plicata Fries & & $\mathrm{L}$ & 1 & seeds & seeds, boiled or for flour \\
\hline Phleum pratense $\mathrm{L}$. & & $\mathrm{N}$ & 2 & seeds & for flour, ff \\
\hline $\begin{array}{l}\text { Setaria pumila (Poir.) Schult. or/and Setaria } \\
\text { viridis (L.) P.Beauv. }\end{array}$ & & NR & 3 & seeds & boiled \\
\hline Fallopia convolvulus (L.) AA.Löve & Polygonaceae & $\mathrm{H}$ & 3 & shoots & boiled, ff \\
\hline Polygonum hydropiper L. & & A & 5 & leaves & raw \\
\hline Polygonum lapathifolium L. ssp. pallidum & & $\mathrm{H}$ & 1 & shoots & fried, ff \\
\hline Rumex acetosa $\mathrm{L}$. & & $\mathrm{H}$ & $1,3,5$ & leaves & raw, cooked \\
\hline Rumex acetosella $\mathrm{L}$. & & $\mathrm{H}$ & 1,3 & leaves & raw, cooked \\
\hline Rumex crispus $\mathrm{L}$. & & A & 6 & leaves & cooked \\
\hline Rumex crispus L. or R. obtusifolius L. & & A & 5,6 & fruit & boiled, ff \\
\hline Rumex hydrolapathum Huds. & & A & 6 & leaves & cooked \\
\hline Rumex obtusifolius L. & & $\mathrm{HU}$ & 2 & leaves & for compotes \\
\hline Rumex thyrsiflorus Fing. & & $\mathrm{H}$ & 2 & leaves & raw, cooked \\
\hline Rumex crispus L. & & $L$ & 1 & leaves, seeds & flour, ff \\
\hline Polypodium vulgare L. & Polypodiaceae & $\mathrm{H}$ & $1,2,3$ & rhizomes & $\begin{array}{l}\text { raw or cooked as } \\
\text { sweetener }\end{array}$ \\
\hline Ranunculus ficaria L. & Ranunculaceae & A & $1,3,6$ & leaves & boiled, raw \\
\hline Nigella sp. & & $\mathrm{L}$ & 1 & seeds & spice \\
\hline Nigella arvensis $\mathrm{L}$. & & A & 6 & seeds & spice \\
\hline Frangula alnus Miller & Rhamnaceae & $\mathrm{NU}$ & 2 & fruits & jams \\
\hline Alchemilla sp. & Rosaceae & $\mathrm{L}$ & 1 & leaves & boiled, ff \\
\hline \multirow[t]{2}{*}{ Crataegus sp. pl. } & & $\mathrm{H}$ & $\begin{array}{l}1,2,3 \\
5\end{array}$ & fruit & raw, wine, jams \\
\hline & & A & 6 & flowers & raw \\
\hline Fragaria vesca $\mathrm{L}$. & & $\mathrm{H}$ & $\begin{array}{l}1,2,3 \\
5\end{array}$ & fruit & raw, wine, jams \\
\hline Malus domestica Borkh. (feral plants) & & $\mathrm{O}$ & $\begin{array}{l}1,2,3 \\
5\end{array}$ & fruit & $\begin{array}{l}\text { raw, compotes or in } \\
\text { sauerkraut }\end{array}$ \\
\hline Potentilla anserina $\mathrm{L}$. & & $L$ & 1 & young shoots & raw \\
\hline \multirow[t]{2}{*}{ Prunus avium L. } & & O & 1 & fruits & raw, compotes \\
\hline & & O & 1 & solidified sap & raw \\
\hline Prunus padus L. & & $\mathrm{H}$ & $\begin{array}{l}1,2,3 \\
5\end{array}$ & fruits & mainly raw \\
\hline
\end{tabular}


Table 6 The list of wild food plants used in Poland since the 19th century (Continued)

\begin{tabular}{|c|c|c|c|c|c|}
\hline \multicolumn{2}{|l|}{ Prunus spinosa L. } & $\mathrm{H}$ & $1,2,3$ & fruits & raw, compotes, jams, wine \\
\hline \multicolumn{2}{|l|}{$\begin{array}{l}\text { Pyrus pyraster (L.) Burgsd. \& Pyrus } \\
\text { communis L. em. Gaertner }\end{array}$} & $\mathrm{O}$ & $\begin{array}{l}1,2,3 \\
5\end{array}$ & fruits & raw, dried, pickled \\
\hline \multicolumn{2}{|l|}{ Rosa sp. pl. (mainly Rosa canina L.) } & $\mathrm{H}$ & $1,2,5$ & fruits & raw, wine, jams, infusions \\
\hline \multicolumn{2}{|l|}{ Rubus caesius L. } & $\mathrm{H}$ & $\begin{array}{l}1,2,3 \\
5\end{array}$ & fruits & raw, wine, jams, infusions \\
\hline \multicolumn{2}{|l|}{ Rubus idaeus L. } & $\mathrm{H}$ & $\begin{array}{l}1,2,3 \\
5\end{array}$ & fruits & raw, wine, jams, infusions \\
\hline \multicolumn{2}{|l|}{ Rubus L. sect. Rubus sp. pl. } & $\mathrm{H}$ & $\begin{array}{l}1,2,3 \\
5\end{array}$ & fruits & raw, wine, jams, infusions \\
\hline \multicolumn{2}{|l|}{ Rubus saxatilis L. } & A & $1,2,5$ & fruits & raw, juice \\
\hline \multicolumn{2}{|l|}{ Sedum maximum (L.) Hoffm. } & $\mathrm{H}$ & 2 & thick roots & unspecified \\
\hline \multicolumn{2}{|l|}{ Sorbus aucuparia L. emend. Hedl. } & $\mathrm{H}$ & $\begin{array}{l}1,2,3 \\
5,6\end{array}$ & fruits & $\begin{array}{l}\text { wine, jams, liqueur, rarely } \\
\text { as spice }\end{array}$ \\
\hline Galium odoratum (L.) Scop. & Rubiaceae & $\mathrm{H}$ & 2 & flowering shoots & spice, infusions \\
\hline V. beccabunga $L$. or $V$. anagallis-aquatica $L$. & Scrophulariaceae & A & 3 & shoots & raw \\
\hline \multirow[t]{4}{*}{ Tilia cordata Miller \& Tilia platyphyllos Scop. } & Tiliaceae & $\mathrm{H}$ & 1,2 & flowers & infusion \\
\hline & & $\mathrm{O}$ & 2 & cambium & raw \\
\hline & & $\mathrm{O}$ & 3 & seeds & oil \\
\hline & & $\mathrm{O}$ & 3,4 & leaves & boiled or into flour, ff \\
\hline Trapa natans L. & Trapaceae & $L$ & 1 & leaves & raw, boiled, flour \\
\hline Typha latifolia L. & Typhaceae & A & 5,6 & shoots and rhizomes & boiled, roasted \\
\hline Ulmus sp. & Ulmaceae & $N$ & 2 & fruits, leaves & unspecified \\
\hline Urtica dioica L. \& Urtica urens L. & Urticaceae & $\mathrm{H}$ & $1,2,3$ & shoot tops & boiled, infusions \\
\hline Parthenocissus sp. & Vitaceae & $\mathrm{H}$ & 2 & fruits & fermented drink \\
\hline Viola arvensis Murr. & Violaceae & $A$ & 5 & flowers & raw \\
\hline
\end{tabular}

The credibility of identification: $\mathrm{H}$ - confirmed by voucher specimen; A - confirmed by a reliable professional or amateur botanist; $\mathrm{O}$ - obvious common name universally used in a large area; L - probable Latin name or scientific name used in the language of a given country, given by a non-botanist; $\mathrm{N}$ - determined using comparative analysis of folk names; $\mathrm{R}$ - determined with the help of the data of a species range or/and habitat; $U$ - highly uncertain; $\mathrm{ff}$ - used only as famine food. Source: 1 - [65], 2 - [79], 3 - [80], 4 - [81], 5 - [82], 6 - [83].

contrast to a few authors who frequently misnamed the plants they had studied.

It must be noted that there is a significant difference between the mean percentage of mistakes detected in the studied works without voucher specimens $(6.2 \%)$ and the level of errors found in the works documented by voucher specimens $(9.2 \%)$. This also illustrates that even in works documented by a herbarium, gross mistakes can occur when the specimens are not verified by a good taxonomist. Single voucher specimens impose yet another threat: although the plant was correctly identified in the field or due to a widely known folk name a specimen of the wrong plant may be collected. This may have happened to Orzeszkowa. Her herbarium contains a specimen of Hepatica nobilis identified as 'kopytnik' Asarum europaeum. The name kopytnik is universally used throughout Poland to name Asarum, so Orzeszkowa may have collected a wrong specimen as both species have evergreen leaves of similar size and grow in the same habitat (identification scenario 1.1 or 1.2.2.1.2 in the Background chapter).

It must be emphasized that the main source of errors in the analyzed literature was the confusion of local names with Polish official names (scenario 2.1.3 in the Background chapter). This probably occurred by the researcher looking up a particular local name in a plant guide and then automatically assigning to it the Latin binominal of a different genus whose official name was identical to the local name of the studied species.

The studied papers usually contained little or no methodological information, so in most cases we cannot be sure if mistakes arose with or without seeing the actual studied plants in the field.

Most errors in the identification of voucher specimens occurred within the same genus, and only $24 \%$ of genera were misidentified. In contrast with this, $48 \%$ of mistakes detected in the publications without voucher specimens concern incorrectly identified genera. As the total number of detectable mistakes in the studies without voucher specimens is roughly four times lower than that of the studies with voucher specimens $(2.3 \%$ versus $10 \%$ ), we can assume that three quarters of all the errors and half of the misidentified genera remained undetected in the studies without voucher specimens.

It is a matter of dispute whether there should be separate codes for voucher specimens identified by an expert 
in the field and for those identified by a non-specialist (e.g. a separate code E could be used for a taxonomic expert). This could be useful, but on the other hand it is very difficult to draw a line between these two categories. As a rule, all voucher specimens should be identified/verified by a specialist - in case of easily identified taxa - a botanist, and in the case of critical taxa (in the Polish flora: Rubus, Rosa, Hieracium, Oenothera, Alchemilla) - a specialized taxonomist, or the specimens should be identified only to the genus, subgenus or section level $[2-5,19]$.

Fortunately the errors made in the presented publications were rarely repeated later. The only case of erroneous "ghost information" in Polish studies is a list of plant names compiled in two ethnographic works $[70,71]$. This situation contrasts with Swedish publications, which according to Svanberg [8,9] contain numerous ghost data.

In all the studied cases the ethnobotanical herbaria contained species which had been reported in the given region or cultivated there, which supports the idea of using detailed atlases of plant distribution to verify ethnobotanical data. Such biogeographical data could be coupled with estimates of species abundance and distribution in local habitat spectra.

Not all the codes presented in the methodology section were used in the real-life list of edible plants of Poland. Most taxa were identified using the codes $\mathrm{H}$, $\mathrm{A}$ and $\mathrm{L}$, more rarely $\mathrm{O}, \mathrm{N}$ or $\mathrm{R}$. The codes $\mathrm{D}, \mathrm{M}$ and $\mathrm{P}$ were not used. However this list was compiled using numerous voucher specimens (hence code $\mathrm{H}$ predominates) and data from 'reliable' researchers (like Rostafiński and Pirożnikow, hence code A). If a similar list were to be compiled for countries where voucher specimens were not collected, or for earlier periods, the proportion of codes in the list may have been reversed.

An interesting issue is the use of photography to document ethnobotanical studies [86]. Although photographic images cannot replace voucher specimens, they can help to document the use of plants, as many (but not all) taxa can be easily identified to a genus level from photographs [87]. Currently, as many electronic journals allow for the attachment of additional files to an article, authors could be encouraged to provide photographs of voucher specimens. Or perhaps we could start thinking about a service of online depositories of photographs of voucher specimens? Yet another option for plant identification, almost exclusively concerning historical ethnobotany, is the identification of plants from drawings (e.g. in old herbals). This is not always easy, but is sometimes possible, particularly when coupled with plant descriptions and folk names $[73,88,89]$.
At the end of this paper the author must confess his own error. While preparing a table for the article on the taxonomic issues in Polish ethnobotanical studies [19], a mistaken name for Veronica chamaedrys was published, i.e. wole oczy instead of żabie oczka. ('ox-eyes' instead of 'frogs' eyes'). This mistake happened when transferring hand-written records to the computer. That is another example of the way errors and "ghost information" can enter ethnobotany, even via a botanist.

\section{Conclusions}

Ethnographic papers without herbarium documentation contain on average at least $6.2 \%$ of mistakes. The verification of voucher specimens can increase this ratio to 9.2\%. These mistakes most often arise by looking up plants using a local name in a botanical guide, and by the lack of cooperation between ethnographers and botanists. The large difference between the ratio of mistakes in the voucher specimen collections and the ratio of detectable mistakes in the literature is an argument for the rigorous use of voucher specimens, which are identified by a specialist, and for creating a service of online depositories of photographs of voucher specimens.

The presented code of credibility may become a useful tool for historical ethnobotany.

\section{Acknowledgements}

I am very grateful to Dr Ingvar Svanberg (Uppsala) for an inspiring discussion on the topic of mistakes in ethnobotanical publications.

\section{Competing interests}

The author declares that they have no competing interests.

Received: 15 October 2010 Accepted: 17 December 2010 Published: 17 December 2010

\section{References}

1. Archer WA: Collecting data and specimens for study of economic plants Washington, D.C.: U.S. Department of Agriculture; 1945, Miscellaneous Publications Publications 568.

2. Bye RA Jr: Voucher specimens in ethnobiological studies and publications. Journal of Ethnobiology 1986, 6(1):1-8.

3. McClatchey W: Improving the Quality of International Ethnobotany Research and Publications. Ethnobotany Research \& Applications 2006, 4:1-9.

4. Martin GJ: Ethnobotany: A Methods Manual London: Chapman and Hall; 1995.

5. Alexiades MN, Sheldon JW, (Eds): Selected Guidelines for Ethnobotanical Research: A Field Manual (Advances in Economic Botany) New York: New York Botanical Garden Pr Dept; 1996.

6. Heinrich M, Kufer J, Leonti M, Pardo-de-Santayana M: Ethnobotany and ethnopharmacology-Interdisciplinary links with the historical sciences. Journal of Ethnopharmacology 2006, 107(2):157-160.

7. Moerman D: Native American Ethnobotany Portland (Oregon): Timber Press; 1998.

8. Svanberg l: Fabulat, plagiat och spökuppgifter: att använda berättande källor inom etnobiologi. In Nycklar till kunskap: om människans bruk av nature. Edited by: Tunón H, Dahlström A. Stockholm: Kungl. Skogs- och Lantbruksakademien; 2010: 
9. Svanberg I: The use of lichens for dyeing candles: ethnobotanical documentation of a local Swedish practice? Svenska Landsmål och Svenskt Folkliv 1998, 324:133-139.

10. Kufer J, Förther H, Pöll E, Heinrich M: Ethnobotany of the Ch'orti'. Journal of Pharmacy and Pharmacology 2005, 57:1127-1152.

11. Soejarto DD: Ethnographic component and organism documentation in an ethnopharmacology passper: A "minimun" standard. Journal of Ethnopharmacology 2005, 100(1-2):27-29.

12. Etkin NL: Perspectives in ethnopharmacology: forging a closer link between bioscience and traditional empirical knowledge. Journal of Ethnopharmacology 2001, 76(2):177-182.

13. de Albuquerque UP, Hanazaki N: Five Problems in Current Ethnobotanical Research-and Some Suggestions for Strengthening Them. Human Ecology 2009, 37(5):653-661.

14. De Natale A, Pezzatti GB, Pollio A: Extending the temporal context of ethnobotanical databases: the case study of the Campania region (southern Italy). Journal of Ethnobiology and Ethnomedicine 2009, 5:7.

15. Skoczen S, Bussmann RW: ebDB - Filling the gap for an international Ethnobotany Database. 2006, 11(2):71-81 [http://www.quantumimagery. com/software-ebDB.html], website Lyonia.

16. Klepacki P: Etnobotanika w Polsce - przeszłość i teraźniejszość. Analecta Studia i Materiały z Dziejów Nauki 2007, 16(1-2):191-245.

17. Köhler P: Zielnik Seweryna Udzieli - dokumentacja pracy „Rośliny W wierzeniach ludu krakowskiego". Lud 1996, 80:179-186.

18. Radwańska-Paryska Z: Zielnik brata Cypriana z Czerwonego Klasztoru Kraków: Instytut Botaniki PAN; 1991, [Polish Botanical Studies Guidebook Series vol. 5.].

19. Łuczaj Ł: Problemy taksonomiczne w polskich badaniach etnobotanicznych. Lud 2008, 92:43-64.

20. Bohdanowicz J: Pożywienie. Zbieractwo - pożywienie głodowe. In Komentarze do Polskiego Atlasu Etnograficznego t. III. Pożywienie i sprzęty z nim zwiqzane. Edited by: Bohdanowicz J. Wrocław: Polskie Towarzystwo Ludoznawcze; 1996:10-21.

21. Chętnik A: Pożywienie Kurpiów. Jadło i napoje zwykłe, obrzędowe i głodowe. Prace Komisji Etnograficznej 1936, 16:1-134

22. Dekowski JP: Rośliny dziko rosnące $w$ tradycyjnym pożywieniu chłopów kozienickich. In Pożywienie ludności wiejskiej. Edited by: Kowalska-Lewicka A. Kraków: Muzeum Etnograficzne w Krakowie; 1973:247-256.

23. Dekowski JP: Z badań nad pożywieniem ludu łowickiego. Prace i Materiały Muzeum Archeologicznego i Etnograficznego w Łodzi. Seria Etnograficzna 1968, 12:1-245.

24. Dydowiczowa J: Zbieractwo. In Kultura ludowa Wielkopolski Volume 2. Edited by: Burszta W. Poznań: Wydawnictwo Poznańskie; 1964:299-328.

25. Eljasz-Radzikowski S: Polscy górale tatrzańscy. Lud 1897, 3:225-272.

26. Gajkowa O: Kultura ludowa okolic Hor i Potylicza. Prace i Materiały Etnograficzne 1947, 6:38-76.

27. Gawełek F: Przesądy, zabobony, środki lecznicze i wiara ludu w Radłowie, w pow. Brzeskim. Materyały Antropologiczno-A rcheologiczne i Etnograficzne 1910, 11:48-89.

28. Gustawicz B: O korzeniach czarodziejskich w lecznictwie ludowem u nas i gdzie indziej. Lud 1904, 10:259-279.

29. Henslowa M: Rośliny dziko rosnace w kulturze ludu polskiego Wrocław: Polskie Towarzystwo Ludoznawcze; 1962.

30. Janicka-Krzywda U: Podstawowe produkty używane do przygotowania pożywienia. In Kalendarz 2004 - z informacjami co się dawniej jadło i piło i z czego sie pod Babia Góra strawe robiło oraz z przepisami kulinarnymi dawnymi i nowszymi. Edited by: Kociołek J. Zawoja: Stowarzyszenie Gmin Babiogórskich; 2004:10-14.

31. Jostowa W: Pożywienie pasterzy, zbójników i myśliwych tatrzańskich. Wiedza i Życie 1954, 21:96-98

32. Kantor J: Czarny Dunajec: monografia etnograficzna. Materyały Antropologiczno-Archeologiczne i Etnograficzne 1907, 9:21-115.

33. Kolberg O: Krakowskie. Cześć III. Dzieła Wszystkie t. 7 Wrocław - Poznań Polskie Towarzystwo Ludoznawcze; 1962, (1874).

34. Kolberg O: W. Ks. Poznańskie. Część VII., Dzieła Wszystkie t. 15 Wrocław Poznań: Polskie Towarzystwo Ludoznawcze; 1962, (1882).

35. Kolberg O: Chełmskie. Cześć Il.Dzieła Wszystkie t. 34 Wrocław - Poznań: Polskie Towarzystwo Ludoznawcze; 1962, (1891)

36. Kolberg O: Sanockie-Krośnieńskie, Część III. Dzieła Wszystkie t. 51 Wrocław Poznań: Polskie Towarzystwo Ludoznawcze; 1973.
37. Kolberg O: Pokucie. Część III. Dzieła Wszystkie t. 31 Wrocław - Poznań: Polskie Towarzystwo Ludoznawcze; 1963, (1888).

38. Kolberg O: Góry i Podgórze. Część. II.Dzieła Wszystkie t. 45 Wrocław - Poznań: Polskie Towarzystwo Ludoznawcze; 1968.

39. Libera Z, Paluch A: Lasowiacki zielnik. Varia Kolbuszowskie 2 Kolbuszowa: Biblioteka Publiczna Miasta i Kminy w Kolbuszowej; 1993.

40. Łęga W: Ziemia Chełmińska. Prace i Materiały Etnograficzne 1961, 17:1-494

41. Malicki Z: Zbieractwo roślin i produktów dzikich na Pomorzu. Litery 1971, 9:14-16.

42. Ochrymowicz J: Pojęcia ludowe o niektórych ziołach. Wisła 1900, 14:332-338.

43. Oczykowski R: Poszukiwania. Wisła 1896, 10:123-124.

44. Orzeszkowa E: Ludzie i kwiaty nad Niemnem. Wisła 1888, 2:1-15.

45. Orzeszkowa E: Ludzie i kwiaty nad Niemnem. Wisła 1891, 5:235-247.

46. Paluch A: Świat roślin w tradycyjnych praktykach leczniczych wsi polskiej Wrocław: Wydawnictwo Uniwersytetu Wrocławskiego; 1984, [Staniszewska M (Series Editor): Acta Universitatis Wratislaviensis vol 752.].

47. Pietkiewicz C: Polesie Rzeczyckie Kraków: Polska Akademia Umiejętności: 1928.

48. Plichta P: Przyczynki zebrane w Sokołowie pod Rzeszowem (w Galicji zachod.). Wisła 1891, 5:638-642

49. Ruszel K: Leksykon kultury ludowej w Rzeszowskiem Rzeszów: Muzeum Okręgowe w Rzeszowie; 2004.

50. Siarkowski W: Przyczynek do lecznictwa ludowego ze wsi Mstyczowa, pow. Jędrzejowskiego, gub. Kieleckiej. Wisła 1890, 4:879-880.

51. Siarkowski W: Przyczynek do lecznictwa ludowego we wsi Korytnica, powiatu Jędrzejowskiego, gubernji Kieleckiej, pod miasteczkiem Sobkowem. Wisła 1891, 5:203-204.

52. Sulisz J: Zapiski etnograficzne z Ropczyc. Lud 1906, 12:57-81.

53. Sulisz J: Zwyczaje wielkanocne w Sanockiem. Lud 1906, 12:309-318

54. Szot-Radziszewska E: Sekrety ziół. Wiedza ludowa, magia, obrzędy, leczenie Warszawa: Trio; 2005

55. Szromba-Rysowa Z: Zbieranie i użytkowanie płodów naturalnych. In Stare i Nowe Siołkowice. Czesść 2. Edited by: Gładysz M. Wrocław-WarszawaKraków: Instytut Historii Kultury Materialnej Polskiej Akademii Nauk; 1966:147-159, [Dynowski W (Series Editor): Biblioteka Etnografii Polskiej, vol. 12.]

56. Szukiewicz W: Wierzenia i praktyki ludowe (zabobony, wróżby, przesądy itd.) zebrane w gubernji Wileńskiej. Wisła 1903, 17:432-444.

57. Szulczewski JW: Pieśń bez końca. Zbiór tekstów folklorystycznoetnograficznych pod redakcją Wojciecha Łysiaka. Poznań: PSO; 1996, (1997).

58. Szychowska-Boebel B: Tradycyjne lecznictwo ludowe na Kujawach Toruń: Muzeum Etnograficzne w Toruniu; 1972.

59. Szychowska-Boebel B: Tradycyjne lecznictwo ludowe Wiela i okolicznych wsi. Rocznik Muzeum Etnograficznego w Toruniu 1978, 1:75-126.

60. Tylkowa D: Medycyna ludowa w kulturze wsi Karpat Polskich Wrocław: Ossolineum; 1988.

61. Udziela S: Rośliny w wierzeniach ludu krakowskiego. Lud 1931, 30:36-75.

62. Wawrzeniecki M: Nieco o roślinach, z których wite są wianki, święcone na Boże Ciało. Wisła 1916, 20(1):19-23.

63. Weryho W: Z medycyny ludowej. Wisła 1888, 2:604-607.

64. Wysłouchowa M: Przyczynki do opisu wsi Wisły w Cieszyńskiem. Lud 1896, 2:126-141.

65. Łuczaj Ł, Szymański WM: Wild vascular plants gathered for consumption in the Polish countryside: a review. Journal of Ethnobiology and Ethnomedicine 2007, 3:17 [http://www.ethnobiomed.com/content/3/1/17].

66. Maurizio A: Pożywienie roślinne w rozwoju dziejowym Warszawa: Kasa Mianowskiego; 1926

67. Moszyński K: Kultura ludowa słowian Kraków: Polska Akademia Umiejętności;1929-1939.

68. Moszyński K: O sposobach badania kultury materialnej Prasłowian Wrocław: Zakład Narodowy im. Ossolińskich; 1962, [Dynowski S (Series Editor): Biblioteka Etnografii Polskiej vol. 6.].

69. Rostafiński J: Zielnik czarodziejski to jest zbiór przesądów o roślinach. Zbiór Wiadomości do Antropologii Krajowej 1895, 18(2):1-191.

70. Duszeńko-Król E, Libera Z: Rośliny lecznicze (nazwy występujące w układzie gniazdowym). In Układ gniazdowy terminów i słownik słów kluczowych wybranych kategorii kultury. Medycyna ludowa. Edited by: Robotycki C, Babik W. Kraków: Wydawnictwo Uniwersytetu Jagiellońskiego; 2005:121-135. 
71. Penkala-Gawęcka D: Medycyna. Słownik. In Układ słów kluczowych dla bazy danych o źródłach etnografi cznych (kultura ludowa Karpat polskich). Edited by: Rybotycki C. Kraków: Wydawnictwo Uniwersytetu Jagiellońskiego; 2005:s. 107-138.

72. Tardío J, Pardo-de-Santayana M: Cultural Importance Indices: A Comparative Analysis Based on the Useful Wild Plants of Southern Cantabria (Northern Spain). Economic Botany 2008, 62:24-39.

73. Leonti M, Cabras S, Weckerle C, Solinas MN, Casu L: The causal dependence of present plant knowledge on herbals-Contemporary medicinal plant use in Campania (Italy) compared to Matthioli (1568). Journal of Ethnopharmacology 2010, 130:379-391.

74. Tardío J, Pardo de Santayana M, Morales R: Ethnobotanical review of wild edible plants in Spain. Botanical Journal of the Linnean Society 2006, 152(1):27-72.

75. Zając A, Zając M, (Eds): Atlas rozmieszczenia roślin naczyniowych w Polsce Kraków: Uniwersytet Jagielloński; 2001.

76. Matuszkiewicz JM: Krajobrazy roślinne i regiony geobotaniczne Polski. Prace Geograficzne 1993, 158:5-107.

77. Kielak AM: O kresowym zielniku Elizy Orzeszkowej Warszawa-Lida: Retro-Art; 2005.

78. Kłodnicki Z, Drożdż A: Dzikie rośliny jadalne - materiały, mapy i opracowania tekstowe Pracowni Polskiego Atlasu Etnograficznego. In Dzikie rośliny jadalne: zapomniany potencjał przyrody. Mat. konf. Przemyśl Bolestraszyce 13 września 2007. Edited by: Łuczaj Ł. Bolestraszyce: Arboretum i Zakład Fizjografii, Bolestraszyce; 2008:109-124.

79. Łuczaj Ł: Archival data on wild food plants eaten in Poland in 1948. Journal of Ethnobiology and Ethnomedicine 2008, 4:4 [http://www. ethnobiomed.com/content/4/1/4].

80. Łuczaj $Ł$ : Dziko rosnące rośliny jadalne $w$ ankiecie Józefa Rostafińskiego $z$ roku 1883. Wiadomości Botaniczne 2008, 52(1/2):39-50.

81. Łuczaj $Ł$ : Changes in the utilization of wild green vegetables in Poland since the 19th century: a comparison of four ethnobotanical surveys. Journal of Ethnopharmacology 2010, 128:395-404.

82. Pirożnikow E: Tradycyjne użytkowania dziko rosnących roślin leczniczych i pokarmowych we wschodniej części Podlasia. In Park krajobrazowy Puszczy Knyszyńskiej w systemie ochrony przyrody i edukacji środowiskowej. Materiały konferencji „Parki krajobrazowe W I połowie XXI wieku - edukacja ekologiczna wczoraj i dziś na przykładzie Parku Krajobrazowego Puszczy Knyszyńnkiej" 27-28 maja 2008 r. Edited by: Górniak A, Poskrobko B. Supraśl: Park Krajobrazowy Puszczy Knyszyńskiej; 2008:64-79.

83. Pirożnikow E: Tradycja użytkowania roślin dziko rosnących na Podlasiu poszukiwanie smaków, zdrowia i zaspokojenia głodu. In Historie kuchenne: Rola i znaczenie pożywienia w kulturze. Edited by: Stolična R, Drożdż A. Cieszyn-Katowice-Brno: Uniwersytet Śląski w Katowicach; 2010:188-200, [Kłodnicki Z, Langer J (Series Editors): Bibliotheca Ethnologiae Europae Centralis vol. 2.].

84. Oklejewicz K: Distribution patterns of the Rubus species (Rosaceae) in the eastern part of the Polish Carpathians. Polish Botanical Studies 2006, 21:1-98.

85. Łuczaj Ł: Zapomniane dzikie rośliny pokarmowe południa Polski czyściec błotny, paprotka zwyczajna, bluszczyk kurdybanek i ostrożeń łąkowy. In Dzikie rośliny jadalne: zapomniany potencjał przyrody. Mat. konf. Przemyśl - Bolestraszyce 13 września 2007. Edited by: Łuczaj Ł. Bolestraszyce: Arboretum i Zakład Fizjografii, Bolestraszyce; 2008:183-199.

86. Thomas E, Vandebroek I, Van Damme P: What Works in the Field? A Comparison of Different Interviewing Methods in Ethnobotany with Special Reference to the Use of Photographs. Economic Botany 2007, 61(4):376-384.

87. Łuczaj $Ł$ : Herbal bouquets blessed on Assumption Day in south-eastern Poland: freelisting versus photographic inventory. Ethnobotany Research and Applications .

88. Picó B, Nuez F: Minor crops of Mesoamerica in early sources (I). Leafy vegetables. Genetic Resources and Crop Evolution 2000, 47:527-540.

89. Picó B, Nuez F: Minor crops of Mesoamerica in early sources (II). Herbs used as condiments. Genetic Resources and Crop Evolution 2000, 47:541-552.

doi:10.1186/1746-4269-6-36

Cite this article as: Łuczaj: Plant identification credibility in ethnobotany: a closer look at Polish ethnographic studies. Journal of Ethnobiology and Ethnomedicine 2010 6:36.

\section{Submit your next manuscript to BioMed Central and take full advantage of:}

- Convenient online submission

- Thorough peer review

- No space constraints or color figure charges

- Immediate publication on acceptance

- Inclusion in PubMed, CAS, Scopus and Google Scholar

- Research which is freely available for redistribution

Submit your manuscript at www.biomedcentral.com/submit 